\title{
Platelets in Asthma: Does Size Matter?
}

\author{
Paul Stoll Marek Lommatzsch \\ Department of Pneumology and Critical Care Medicine, University of Rostock, Rostock, Germany
}

Platelets are anucleated cells which are small in size, simple in structure, and phylogenetically older than leukocytes. Therefore, these cells are often neglected and their function is thought to be limited to hemostasis. However, there is now a growing body of evidence that platelets play an essential role in various inflammatory diseases [1]. The overwhelming number and turnover of these cells in the human body (about 100 billion new platelets are released daily from bone marrow megakaryocytes), the unique ability of platelets to incorporate, store, and release mediators, and the multiple interactions of these cells with leukocytes and endothelial cells led to the concept that platelets are crucial players in the innate and adaptive immune responses of mammals [1]. It is therefore not surprising that there have been major efforts to elucidate the role of platelets in chronic inflammatory diseases such as asthma [2]. Data from animal models of asthma suggest that platelets infiltrate the airway wall after an allergen challenge, either by active migration [3] or by passive migration in platelet-leukocyte aggregates [4], contributing to airway remodeling [5] and the development of airway hyperresponsiveness [6]. Clinical studies have shown a more complex picture of the platelet in asthma. On the one hand, platelets from patients with asthma are characterized by an increased

\section{KARGER}

E-Mail karger@karger.com

www.karger.com/res activation and an increased release of growth factors such as brain-derived neurotrophic factor (BDNF) [7-11]. On the other hand, platelets from patients with asthma have been postulated to be less responsive to various stimulants such as collagen, adenosine diphosphate (ADP) [12], platelet-activating factor (PAF) [13], and arachidonic acid [14], suggesting that platelets might be 'exhausted' as a consequence of chronic activation [15]. Thus, the precise phenotype and role of platelets in patients with asthma are still incompletely understood.

In this issue of Respiration, Sun et al. [16] investigate the mean platelet volume (MPV) of 85 patients with stable asthma and of 85 patients with exacerbated asthma and compare the results to those of a group of 85 healthy volunteers matched for age, gender, BMI, and smoking history. The authors show that patients with stable asthma display a significantly lower MPV (10.3 fl) compared to healthy controls (10.7 fl). In patients with an acute exacerbation of asthma, the MPV was even lower (9.8 fl) and correlated negatively with their serum levels of Creactive protein. These results add new evidence to the ongoing discussion on the role and phenotype of platelets in asthma. It might be speculated that 'exhausted' platelets are smaller in size due to chronic activation and chronic mediator release. However, the neurotrophin
(C) 2014 S. Karger AG, Basel

0025-7931/14/0881-0022\$39.50/0
Prof. Dr. Marek Lommatzsch

Abteilung für Pneumologie und Interdisziplinäre Internistische Intensivmedizin Zentrum für Innere Medizin, Universitätsmedizin Rostock

Ernst-Heydemann-Strasse 6, DE-18057 Rostock (Germany)

E-Mail marek.lommatzsch@med.uni-rostock.de 
BDNF, a mediator stored in platelet $\alpha$-granules which regulates neuronal plasticity, has been shown to be increased in the circulating platelets of patients with stable asthma, suggesting that there is no general depletion of all mediators in the platelet in this disease [10]. Therefore, further research is needed to elucidate the precise characteristics of platelets in asthma.

There are two main caveats when interpreting the results of Sun et al. [16]. First, a decrease in MPV and specific changes in platelet mediators have also been shown in patients with chronic obstructive pulmonary disease [17-19]. Thus, the observed changes in platelet characteristics might be a common feature of chronic inflammatory airway diseases rather than a specific feature of asth- ma. Second, genome-wide association studies have estimated that the phenotypic variance caused by the cumulative effects of more than 60 known polymorphisms lead to MPV differences of up to 9.9\% [20]. The difference in MPV between patients with stable asthma and the group of healthy volunteers described by Sun et al. [16] was less than $4 \%$. Thus, a relevant impact of genetic backgrounds and polymorphisms on the observed difference in MPV between the groups cannot be excluded. Longitudinal studies comparing MPVs of patients with asthma in various states of the disease are therefore needed to better understand the specific regulation and role of MPV in asthma.

\section{References}

1 Semple JW, Italiano JE Jr, Freedman J: Platelets and the immune continuum. Nat Rev Immunol 2011;11:264-274.

-2 O'Sullivan BP, Michelson AD: The inflammatory role of platelets in cystic fibrosis. Am J Respir Crit Care Med 2006;173:483-490.

3 Pitchford SC, Momi S, Baglioni S, Casali L, Giannini S, Rossi R, Page CP, Gresele P: Allergen induces the migration of platelets to lung tissue in allergic asthma. Am J Respir Crit Care Med 2008;177:604-612.

-4 Pitchford SC, Yano H, Lever R, Riffo-Vasquez Y, Ciferri S, Rose MJ, Giannini S, Momi S, Spina D, O'Connor B, Gresele P, Page CP: Platelets are essential for leukocyte recruitment in allergic inflammation. J Allergy Clin Immunol 2003;112:109-118.

5 Pitchford SC, Riffo-Vasquez Y, Sousa A, Momi S, Gresele P, Spina D, Page CP: Platelets are necessary for airway wall remodeling in a murine model of chronic allergic inflammation. Blood 2004;103:639-647.

6 Coyle AJ, Spina D, Page CP: PAF-induced bronchial hyperresponsiveness in the rabbit: contribution of platelets and airway smooth muscle. Br J Pharmacol 1990;101:31-38.

7 Yamamoto H, Nagata M, Tabe K, Kimura I, Kiuchi H, Sakamoto Y, Yamamoto K, Dohi Y: The evidence of platelet activation in bronchial asthma. J Allergy Clin Immunol 1993; 91:79-87.
8 Johnson CE, Belfield PW, Davis S, Cooke NJ, Spencer A, Davies JA: Platelet activation during exercise induced asthma: effect of prophylaxis with cromoglycate and salbutamol. Tho$\operatorname{rax} 1986 ; 41: 290-294$.

-9 Moritani C, Ishioka S, Haruta Y, Kambe M, Yamakido M: Activation of platelets in bronchial asthma. Chest 1998;113:452-458.

10 Lommatzsch M, Schloetcke K, Klotz J, Schuhbaeck K, Zingler D, Zingler C, Schulte-Herbruggen $\mathrm{O}$, Gill $\mathrm{H}$, Schuff-Werner P, Virchow JC: Brain-derived neurotrophic factor in platelets and airflow limitation in asthma. Am J Respir Crit Care Med 2005;171:115120.

11 Lommatzsch M, Lindner Y, Edner A, Bratke K, Kuepper M, Virchow JC: Adverse effects of salmeterol in asthma: a neuronal perspective. Thorax 2009;64:763-769.

12 Szczeklik A, Milner PC, Birch J, Watkins J, Martin JF: Prolonged bleeding time, reduced platelet aggregation, altered PAF-acether sensitivity and increased platelet mass are a trait of asthma and hay fever. Thromb Haemost 1986;56:283-287.

13 Beer JH, Wuthrich B, von Felten A: Allergen exposure in acute asthma causes the release of platelet-activating factor (PAF) as demonstrated by the desensitization of platelets to PAF. Int Arch Allergy Immunol 1995;106: 291-296.
14 Szczeklik A, Krzanowski M, Nizankowska E, Musial J: Bleeding time and PAF-acether-induced platelet aggregation in atopy. Agents Actions Suppl 1987;21:145-150.

15 Kornerup KN, Page CP: The role of platelets in the pathophysiology of asthma. Platelets 2007;18:319-328.

16 Sun W-X, Zhang J-R, Cao Z, Li Y, Wang R: A decreased mean platelet volume is associated with stable and exacerbated asthma. Respiration 2014;88:31-37.

17 Biljak VR, Pancirov D, Cepelak I, PopovicGrle S, Stjepanovic G, Grubisic TZ: Platelet count, mean platelet volume and smoking status in stable chronic obstructive pulmonary disease. Platelets 2011;22:466-470.

18 Wang RT, Li JY, Cao ZG, Li Y: Mean platelet volume is decreased during an acute exacerbation of chronic obstructive pulmonary disease. Respirology 2013;18:1244-1248.

19 Stoll P, Wuertemberger U, Bratke K, Zingler C, Virchow JC, Lommatzsch M: Stage-dependent association of BDNF and TGF-betal with lung function in stable COPD. Respir Res 2012;13:116.

20 Gieger C, Radhakrishnan A, Cvejic A, et al: New gene functions in megakaryopoiesis and platelet formation. Nature 2011;480:201-208. 